\title{
PENDUGAAN LIMBAH ORGANIK BUDIDAYA UDANG KARANG DALAM KERAMBA JARING APUNG TERHADAP KUALITAS PERAIRAN TELUK EKAS PROVINSI NUSA TENGGARA BARAT
}

\author{
Muhammad Junaidi \\ Program Studi Budidaya Perairan, Universitas Mataram \\ Email : junaidi_md@yahoo.co.id
}

\begin{abstract}
ABSTRAK
Penelitian ini bertujuan untuk mendapatkan data dan informasi mengenai jumlah (kuantitatif) limbah organik (N, P dan C) dari kegiatan budidaya udang karang dalam keramba jaring apung (KJA), dan pengaruh kegiatan budidaya udang karang terhadap status kualitas perairan Teluk Ekas Provinsi Nusa Tenggara Barat dalam hubunganya dengan kelayakan perairan tersebut untuk pengembangan budidaya perikanan Iaut. Pendugaan total bahan organik dihitung dengan mengacu pada total pakan yang tidak dikonsumsi dan jumlah feses. Pengumpulan limbah feses dan sisa pakan dilakukan setiap bulan selama kegiatan budidaya udang karang. Metode pengambilan dan penanganan contoh air mengacu pada APHA (1992), analisis data kualitas air dengan Principal Component Analysis, serta penentuan status kualitas perairan Teluk Ekas dengan Nemerow Pollution Index (PI).

Selama pemeliharaan udang karang yang berlangsung 270 hari dengan pemberian pakan ikan rucah, diperoleh laju pertumbuhan harian adalah 0,74 g/hari, sintasan $66 \%$ dan dengan rasio konversi pakan 11,15. Beban limbah budidaya udang karang dalam KJA yang terbuang ke lingkungan perairan sebanyak $1.256,38 \mathrm{kgN} ; 259,26 \mathrm{kgP}$ dan $2.212,91 \mathrm{kgC/ton}$ produksi udang. Status kualitas perairan Teluk Ekas termasuk kriteria tercemaran sedang sampai tercemar berat, dimana parameter yang melebihi baku mutu adalah amonia $(0,3 \mathrm{mg} / \mathrm{l})$, nitrat $(0,008 \mathrm{mg} / \mathrm{l})$, dan fosfat $(0,015 \mathrm{mg} / \mathrm{l})$. Dengan demikian, untuk mengantisipasi penurunan kelayakan habitat dan dampaknya terhadap lingkungan perairan budidaya, maka perlu mencari upaya-upaya yang dapat menekan laju buangan limbah tersebut ke dalam lingkungan budidaya, sehingga dapat meminimalkan dampak kegiatan budidaya dalam perairan tersebut.
\end{abstract}

Kata kunci : limbah organik, budidaya udang karang, keramba jaring apung, kualitas air, Teluk Ekas 


\section{PENDAHULUAN}

Teluk Ekas yang terletak di bagian selatan Pulau Lombok, Provinsi Nusa Tenggara Barat yang berhadapan langsung dengan Samudera Hindia dan memiliki mulut yang sempit sehingga merupakan penghalang bagi masuknya energi yang besar ke perairan teluk dalam. Keadaan ini dapat menguntungkan karena perairan teluk dalam menjadi relatif tenang, yang bermanfaat bagi kegiatan pengembangan budidaya laut (Aslianti et al., 2003). Sejak tahun 2000 di Teluk Ekas berkembang budidaya udang karang (lobster) dalam keramba jaring apung (KJA). Pada waktu itu banyak ditemukan benih alam yang menempel pada pelampung dan material lain yang berkaitan dengan budidaya rumput laut dan kerapu (Priyambodo and Jaya, 2009; Priyambodo and Sarifin, 2009; Priyambodo and Sarifin, 2010; Jones et al., 2010; Jones, 2010), kemudian benih-benih tersebut diambil dan dipelihara dalam KJA, sehingga kegiatan budidaya udang karang terus berkembang sampai saat ini.

Budidaya udang karang dalam KJA di perairan Teluk Ekas sepenuhnya mengandalkan pakan berupa ikan rucah (trash fish), yang merupakan hasil samping perikanan tangkap. Walaupun harganya murah, dampak lingkungan akibat penggunaan pakan ikan rucah cukup nyata, dimana ikan rucah memiliki residu limbah lebih tinggi dibanding pakan buatan (Hansen et al., 1990; Chu, 2000), sebaran dampak lebih luas (Wu et al. 1994), dan proses degradasi bahan organik pakan ikan rucah relatif lambat (Junaidi et al., 2014). Pada budidaya ikan secara intensif, jumlah pakan yang diberikan sebanyak 30\% tertinggal sebagai sisa pakan yang tidak dikonsumsi dan $25-30 \%$ pakan yang dikonsumsi akan dieksresikan (McDonald et al., 1996). Jumlah masukan pakan tersebut berpotensi sebagai penyumbang nutrient dalam perairan yang bersumber dan pakan yang tidak termakan dan feses dan dapat memicu tingkat kesuburan perairan. Beberapa hasil penelitian melaporkan bahwa kegiatan budidaya laut berdampak pada eutrofikasi ekosistem dan kematian ikan dan bentos (Pearson dan Black, 2001; Islam, 2005; Puscedd et al., 2007).

Pelarutan nutrient terutama nitrogen (N) dan fosfat (P) ke lingkungan perairan tersebut menjadi penting untuk diperhatikan dalam manajemen budidaya karena merupakan nutrient makro yang dibutuhkan oleh fitoplankton dan berperan dalam produktivitas primer pada ekosistem akuatik (Boyd, 1990). Input nutrient tersebut ke badan air yang berlebih dapat meningkatkan konsentrasi nutrient dan peledakan populasi fitoplankton. Disamping itu, tingginya kandungan bahan tersebut mengakibatkan adanya suatu peningkatan terhadap rendahnya tingkat oksigen terlarut pada area yang luas, tingginya 
kandungan BOD dan konsentrasi ammonia di dalam kolom perairan (Warren, 1982). Namun demikian, besaran dampak lingkungan pada budidaya laut sistem KJA selain dipengaruhi oleh konversi pakan (Yosmaniar, 2010), juga ditentukan oleh ukuran unit KJA, kepadatan ikan, durasi pengoperasian KJA, kondisi biofisik dan oseanografi perairan, biota yang menghuni kawasan tersebut, dan kapasitas assimilasi dari lingkungan (Milewski, 2001).

Penurunan kelayakan kualitas air sebagai dampak operasional budidaya dapat mempengaruhi kehidupan bahkan kematian stok ikan budidaya sehingga menggagalkan panen serta terjadinya penurunan produktivitas lahan. Untuk mengantisipasi penurunan kelayakan habitat dampaknya terhadap lingkungan perairan wilayah pesisir, maka penting untuk melakukan pendugaan beban limbah nutrient dari kegiatan perikanan budidaya udang karang dalam KJA di laut. Penelitian ini bertujuan untuk mendapatkan data dan informasi mengenai jumlah (kuantitatif) limbah organik (N, P dan $\mathrm{C}$ ) dari kegiatan budidaya udang karang dalam KJA, dan pengaruh kegiatan budidaya udang karang dalam KJA terhadap status kualitas perairan Teluk Ekas Provinsi Nusa Tenggara Barat dalam hubunganya dengan kelayakan perairan tersebut untuk pengembangan budidaya perikanan Iaut.

\section{BAHAN DAN METODE Tempat dan Waktu}

Penelitian dilakukan di perairan Teluk Ekas Provinsi NTB (Gambar 1). Wilayah Teluk Ekas secara administratif berada di dua kabupaten, sebagian besar berada di wilayah Kabupaten Lombok Timur dan sebagian kecil berada di wilayah Kabupaten Lombok Tengah. Penelitian dilakukan pada bulan Januari sampai dengan Oktober 2013.

\section{Budidaya Udang Karang dalam Keramba Jaring Apung}

Percobaan budidaya udang karang dilakukan dalam karamba jaring apung (KJA) ukuran $3 \times 3 \times 3$ $\mathrm{m}^{3}$ sebanyak 3 unit yang diletakkan dalam satu unit rakit. Benih udang karang jenis Panulirus homarus yang berukuran 15, 30, dan 45 g/ekor díperoleh dan tempat pengumpulan di sekitar lokasi budidaya. Sebelum ditebar dilakukan proses adaptasi terhadap pakan dan lingkungan budidaya selama seminggu. Padat penebaran adalah 150 ekor/KJA. Selama masa pemeliharaan yang berlangsung selama 270 bulan diberi pakan berupa ikan rucah (segar). Jumlah pakan yang diberikan adalah 5\% dari biomassa ikan setiap hari dengan pemberian 1 kali sehari pada jam17.00. 


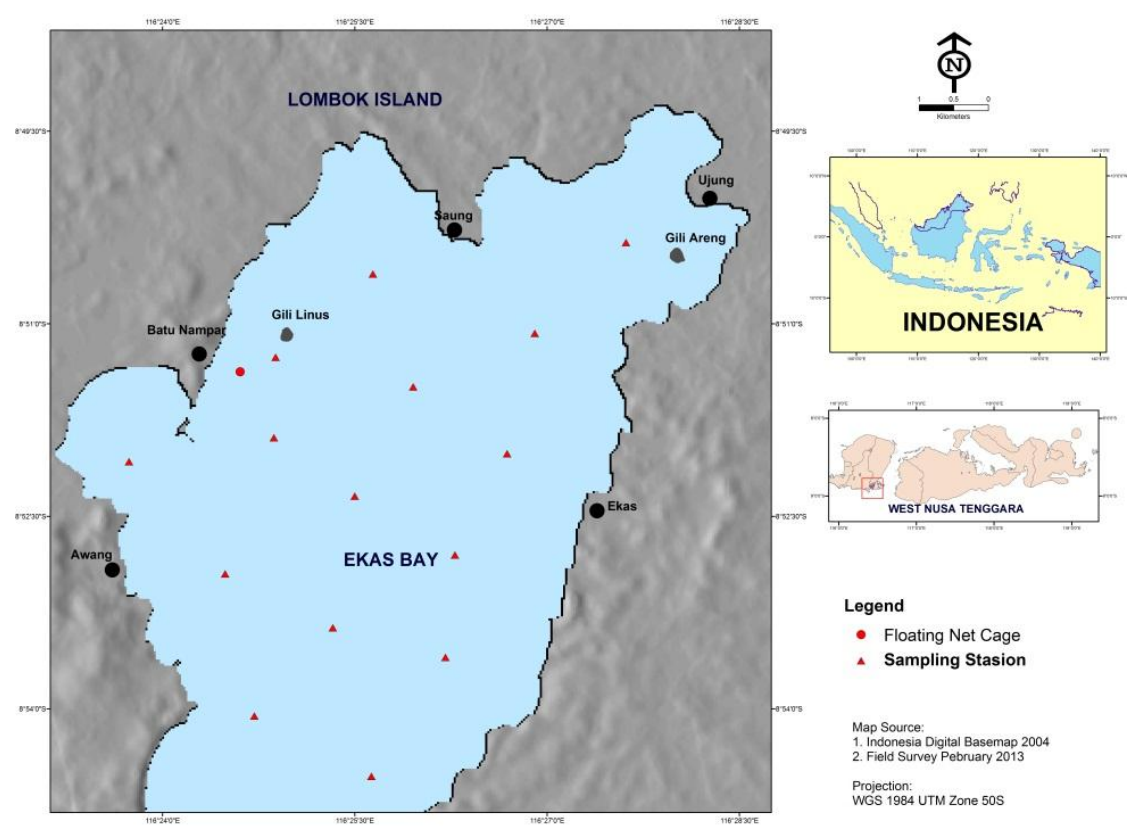

\section{Gambar 1. Lokasi studi, Teluk Ekas Provinsi Nusa Tenggara Barat}

Peubah biologi pertumbuhan diamati setiap bulan dengan cara menimbang sebanyak 15 ekor per keramba dengan alat bantu timbangan dengan ketelitian 0,1 g. Penentuan sintasan, laju pertumbuhan harian $(\mathrm{LPH})$, rasio konversi pakan (RKP) dihitung dengan persamaan sebagai berikut :

- Sintasan $(\%)=$ (jumlah udang yang hidup pada akhìr penelitian / jumlah udang saat tebar) $\mathrm{x} 100 \%$.

- $\mathrm{LPH}(\%)=\left\{(\mathrm{Wt} / \mathrm{Wo})^{1 / \mathrm{t}}-1\right\} \times 100$ (NRC, 1983), dengan $\mathrm{Wt}=$ bobot udang pada akhir penelitian (gt); Wo = bobot ikan pada awal penelitian (g).

- $\mathrm{RKP}=$ jumlah pakan yang dimakan / pertambahan bobot udang

Selama pemeliharaan udang karang selama 9 bulan dilakukan pengukuran kualitas air di KJA dan sekitarnya yang terdiri suhu, salinitas, oksigen terlarut, amoni $\left(\mathrm{NH}_{3}\right)$, nitrat $\left(\mathrm{NO}_{2}\right)$, nitrit $\left(\mathrm{NO}_{3}\right)$, dan fosfat $\left(\mathrm{PO}_{4}\right)$.
Selain itu dilakukan analisis proksimat pakan dan karkas udang karang yang meliputi protein kasar (Mikro Kjeldahl), lemak kesar (Ekstraksi Soxhlet), karbohidrat (Spektrofotometer), serat kasar (Fibretex), kadar abu (Muffle) dan kadar air (pengeringan oven). Untuk mengetahui pengaruh kualitas terhadap sintasan dan LPH dilakukan analisis multivariat dengan metode regresi bertatar (stepwise regression), analisis klaster (cluster analysis) dan analisis komponen utama (principal component analysis) menggunakan software Minitab 14.

\section{Analisis Beban Limbah Budidaya}

Analisis beban limbah budidaya udang karang dalam KJA dilakukan dengan menggunakan kantong berukuran $3,5 \times 3,5 \times 3,5 \mathrm{~m}^{3}$ yang terbuat dari kain halus mesh size 20 mikron. Supaya kantong berbentuk persegi, maka setiap pinggir kantong dipasang tali, dan pada tali yang berada 
keempat sudut kantong dipasang pemberat. Untuk menampung limbah berupa feses dan sisa pakan yang terbuang, maka pada bagian bawah kantong dipasang pipa paralon 5 inci dan panjang $30 \mathrm{~cm}$ serta di bagian ujung bawah dipasang penutup. Kantong penampung limbah dipasang di bagian luar jaring KJA (Gambar 2). Pemasangan kantong dilakukan 24 jam sebelum pengumpulan limbah feses dan sisa pakan.

Pengumpulan limbah feses dan sisa pakan dilakukan setiap bulan sekali yaitu 9 kali (ulangan) sampling selama kegiatan budidaya udang karang. Limbah yang terkumpul kemudian dipisahkan antara feses dan sisa pakan. Baik limbah feses maupun sisa pakan kemudian ditimbang dan selanjutnya dianalisa proximat, kandungan $\mathrm{N}$ (Mikro Kjeldahl), P (metode Bray-I) dan C (metode Walkey Black).

Pendugaan total bahan organik dihitung berdasarkan metode yang dikemukakan oleh Iwama (1991) dan Barg (1992) dengan mengacu pada total pakan yang tidak dikonsumsi dan jumlah feses, dengan persamaan :

$$
\mathrm{O}=\mathrm{TU}+\mathrm{TFW}
$$

dimana $\mathrm{O}=$ total output partikel bahan organik, $\mathrm{TU}=$ total pakan yang tidak dimakan, yang diperoleh dengan persamaan :

$$
\mathrm{TU}=\mathrm{TF} \times \mathrm{UW}
$$

dimana $\mathrm{TF}=$ total pakan yang diberikan $\mathrm{UW}=$ presentase pakan yang tidak dimakan (rasio total pakan yang dimakan terhadap total pakan yang diberikan). $\mathrm{TFW}=$ total limbah feses, dihitung dengan persamaan :

$$
\mathrm{TFW}=\mathrm{F} \times \mathrm{TE}
$$

dimana $F=$ persentase feses (rasio total feses terhadap total pakan yang dimakan), $\quad \mathrm{TE}=$ total pakan yang dimakan, diperoleh dengan persamaan :

$$
\mathrm{TE}=\mathrm{TF}-\mathrm{TU}
$$

dimana $\mathrm{TF}=$ total pakan yang diberikan; $\mathrm{TU}=$ total pakan yang tidak dimakan

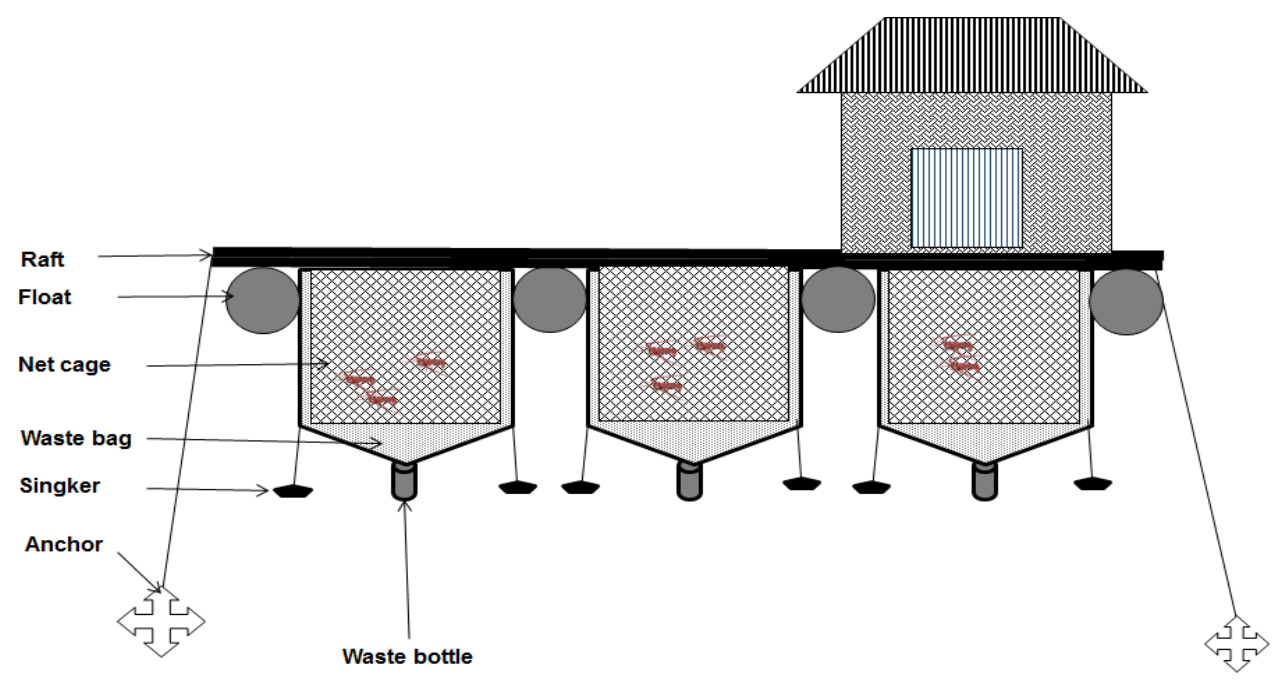

Gambar 2. Keramba jaring apung dengan perangkap feses dan sisa pakan 
Pendugaan kuantifikasi limbah total $\mathrm{N}$ dan $\mathrm{P}$ (TN dan $\mathrm{TP}$ ) didasarkan atas data kandungan $\mathrm{N}$ dan $\mathrm{P}$ dalam pakan ikan rucah, dan dalam karkas udang karang (Beveridge, 1987; Barg, 1992). Pendugaan total $\mathrm{N}$ dan $\mathrm{P}$ mengacu pada metode Ackefors dan Enell (1990) dan Barg (1992), dihitung dengan persamaan sebagai berikut :

Persamaan untuk loading $\mathrm{P}$ adalah :

$$
\mathrm{Kg} \mathrm{P}=(\mathrm{A} \times \mathrm{Cdp})-(\mathrm{B} \times \mathrm{Cfp})
$$

Persamaan untuk loading $\mathrm{N}$ adalah

$$
\mathrm{Kg} \mathrm{N}=(\mathrm{A} \times \mathrm{Cdn})-(\mathrm{B} \times \mathrm{Cfn})
$$

dimana $\mathrm{A}=$ bobot basah pakan rucah yang digunakan $(\mathrm{kg}) ; \mathrm{B}=$ bobot basah udang yang diproduksi $(\mathrm{kg}) ; \mathrm{Cd}=$ kandungan phosphor (Cdp) dan nitrogen (Cdn) di pakan diekspresikan sebagai \% bobot basah; $\mathrm{Cf}=$ kandungan phosphor (Cfp) dan nitrogen (Cfn) dari karkas udang diekspresikan sebagai \% bobot basah.

\section{Penentuan Status Kualitas Perairan Teluk Ekas}

Pengkuran kualitas air dilakukan secara secara in-situ di lapang dan exsitu di laboratorium pada 15 stasiun pengamatan (Gambar 1), pada bulan Januari mewakili musim hujan dan bulan Juli mewakili musim kemarau. Penyusuran stasiun pengamatan dilakukan dengan menggunakan GPS. Pengumpulan data dengan melakukan pengukuran in-situ di lapangan terhadap parameter kualitas air yang meliputi suhu dengan Thermometer, oksigen terlarut dengan Oxygen-Meter, salinitas dengan menggunakan Refraktometer, kecerahan dengan Secchi Disk dan $\mathrm{pH}$ dengan pH-meter. Pengamatan parameter amonia $\left(\mathrm{NH}_{3}\right)$, nitrat $\left(\mathrm{NO}_{3}\right)$, nitrit $\left(\mathrm{NO}_{2}\right)$ dan fosfat $\left(\mathrm{PO}_{4}\right)$ dianalisis secara ex-situ di Laboratorium Penguji Balai Perikanan Budidaya Laut Lombok. Metode analisis yang dipakai untuk menganalisa kualitas air dalam penelitian ini mengacu pada APHA (2005).

Data hasil pengukuran dianalisis dengan menggunakan metode Principal Component Analysis (PCA) yang ditujukan untuk mengekstraksi data kualitas perairan menjadi suatu informasi dalam bentuk matriks yang memiliki kemiripan atau hubungan antar atribut dan dalam bentuk grafik yang mudah diintepretasi (Soedibjo, 2008; Setyobudiandi et al., 2009). Penentuan status tingkat pencemaran lokasi kegiatan budidaya dengan menggunakan metode Nemerow Pollution Index (PI) (Gummadi et al., 2015; Jie et al, 2012) dengan persamaan:

$$
P I=\sqrt{\frac{\left(C_{i} / L_{i j}\right)_{M}^{2}+\left(C_{i} / L_{i j}\right)_{R}^{2}}{2}}
$$

dimana $\mathrm{C}_{\mathrm{i}}=$ konsentrasi parameter kualitas air (i); $\mathrm{L}_{\mathrm{ij}}=$ konsentrasi parameter kualitas air (i) menurut baku mutu kegiatan $(\mathrm{j}) ; \quad\left(\mathrm{C}_{\mathrm{i}} / \mathrm{L}_{\mathrm{ij}}\right)_{\mathrm{M}}=$ nilai parameter relatif maksimum dan $\left(\mathrm{C}_{\mathrm{i}} / \mathrm{L}_{\mathrm{ij}}\right)_{\mathrm{R}}=$ nilai parameter relatif ratarata. Kriteria yang digunakan untuk menentukan apakah perairan Teluk Ekas masih dalam kondisi baik atau telah tercemar jika : $0 \leq \mathrm{PI}_{\mathrm{j}} \leq 1.0=$ kondisi baik; $1.0<\mathrm{IP}_{\mathrm{j}} \leq 5.0=$ tercemar ringan; $5.0<\mathrm{PI}_{\mathrm{j}} \leq 10.0=$ tercemar sedang; $\mathrm{PI}_{\mathrm{j}} \geq$ $10.0=$ tercemar berat $($ Kepmen Negara LH No. 51, 2004). 
HASIL DAN PEMBAHASAN

\section{Keragaan Budidaya Udang Karang dalam KJA}

Selama masa pemeliharaan terjadi pertambahan bobot biomassa udang karang dari 2,25 - 6,75 kg/KJA menjadi $14,35-23,10 \mathrm{~kg} / \mathrm{KJA}$ dengan rata-rata $\mathrm{LPH} \quad 0,59-0,86 \%, \mathrm{RKP}$ sebesar 9,66 - 12,11 dan sintasan 63,33 - $70 \%$. Rasio konversi pakan dan sintasan yang didapatkan dalam penelitian ini relatif sama dengan hasil penelitian ACIAR-SADI, yaitu RKP 12,0 dan sintasan 60\% (Jones, 2010), sedangkan dengan pemberian pakan berupa ikan Sardin (Sardinella spp) sebanyak 10-20\% diperoleh sintasan lebih tinggi yaitu 86,7\% (Becira dan Orcajada, 2006). Laju pertumbuhan harian lebih tinggi dibandingkan penelitian Aslianti et al. (2004) yaitu $0,236 \%$.

Berdasarkan analisis multivariat dengan metode stepwise regression menggunakan software Minitab 14, diperoleh bahwa parameter kualitas air yang mempunyai pengaruh yang besar $(\mathrm{R}-\mathrm{aq}=67.52)$ terhadap sintasan adalah amonia, fosfat dan salinitas. Sedangkan terhadap laju pertumbuhan harian (LPH), dipengaruhi oleh parameter amonia dengan nilai $\mathrm{R}-\mathrm{aq}=32,01$. Hal ini menunjukkan bahwa rendahnya sintasan udang karang yang dipelihara dalam KJA di Teluk Ekas akibat kualitas perairan kurang mendukung proses pertumbuhan dan sintasan udang karang. Pakan yang digunakan dalam budidaya udang karang adalah ikan rucah dengan kandungan protein $42,38 \%$.

Benih udang karang yang dipelihara dalam KJA mempunyai bobot awal antara 15-45 g/ekor dan hasil analisis proksimat karkas udang awal dengan kandungan $\mathrm{N}, \mathrm{P}$ dan $\mathrm{C}$ masingmasing $4,34 \%, 0,92 \%$ dan $8,24 \%$. Sedangkan karkas udang karang berbobot antara 151-220 g/ekor pada akhir pemeliharaan memiliki kandungan $\mathrm{N}, \mathrm{P}$ dan $\mathrm{C}$ masing-masing $5,64 \%, \quad 0,75 \%$ dan $29,79 \%$. Nilai proksimat karkas ini akan digunakan untuk menghitung retensi nutrien pakan. Retensi N, P dan C dalam karkas udang karang masing-masing $25,12 \%, 14,64 \%$ dan $66,83 \%$.

\section{Pendugaan Limbah Budidaya}

Jumlah feses udang karang yang dihasilkan untuk berbagai ukuran relatif beragam berkisar antara 29,67 - 42,00\% bobot kering pakan dengan kandungan $\mathrm{N}, \mathrm{P}$ dan $\mathrm{C}$ masing-masing 2,06\%, 1,85\% dan 12,99\% (Tabel 1). Parameter yang dibutuhkan untuk pendugaan limbah budidaya udang karang diperoleh dari data dan informasi tentang karakteristik pakan, feses, karkas udang 
karang, peubah biologis yang diperoleh dari kegiatan pemeliharaan udang karang dalam KJA (bobot awal, bobot akhir, RKP, produksi biomassa, persentase pakan yang terbuang, retensi dan kecernaan pakan) sebagai acuan untuk mengetahui alur pemanfaatan pakan (Tabel 2).

Berdasarkan Tabel 2, maka untuk memproduksi 1 ton udang karang dibutuhkan pakan sebanyak $11.150 \mathrm{~kg}$ $(\mathrm{RKP}=11,15)$ dengan kandungan $\mathrm{N}, \mathrm{P}$ dan $\mathrm{C}$ pakan masing-masing sebanyak $1.427,20 \mathrm{kgN}, 278,75 \mathrm{kgP}$ dan $3.255,81$ kgC. Sekitar $8.474 \mathrm{~kg}(76 \%)$ dimakan oleh udang atau $1084,67 \mathrm{kgN}, 211,85$ $\mathrm{kgP}$ dan 2.474,41 kgC, dan sisanya $2.676 \mathrm{~kg}(24 \%)$ atau $342,53 \mathrm{kgN}, 66,90$ $\mathrm{kgP}$ dan 781,31 $\mathrm{kgC}$ terbuang $\mathrm{ke}$ lingkungan perairan. Jumlah feses yang dihasilkan $3.121 \mathrm{~kg} / \mathrm{ton}(36 \%)$ atau $401,33 \mathrm{kgN}, 78,38 \mathrm{kgP}$ dan $915,53 \mathrm{kgC}$ juga terbuang ke perairan. Dari $1.084,67 \mathrm{kgN}, 211,85 \mathrm{kgP}$ dan $2.474,41$ $\mathrm{kgC}$ yang dimakan, sisanya sebanyak $683,67 \mathrm{kgN}, 133,47 \mathrm{kgP}$ dan $1.558,88$ $\mathrm{kgC}$ dicerna udang. Dalam proses metabolisme udang, sebanyak 512,51 $\mathrm{kgN}, 113,98 \mathrm{kgP}$ dan 515,99 $\mathrm{kgC}$ akan diekskresikan sisanya masing-masing $170,84 \mathrm{kgN}, 19,49 \mathrm{kgP}$ dan $1.042,89$

Tabel 1. Produksi feses udang karang (\% bobot kering) dan kandungan $N, P$ dan $\mathrm{C}$ feses selama pemeliharaan

\begin{tabular}{|c|c|c|c|c|c|}
\hline $\begin{array}{l}\text { Pemeliharaan } \\
\text { hari ke }\end{array}$ & $\begin{array}{l}\text { Bobot udang } \\
\text { karang }\end{array}$ & $\begin{array}{l}\text { Bobot feses } \\
\text { terhadap pakan } \\
\text { (\% BK } \pm S D ;\end{array}$ & $\mathrm{N}(\%)$ & $\mathrm{P}(\%)$ & C (\%) \\
\hline
\end{tabular}

$\mathrm{kgC}$ akan diretensikan ke dalam daging udang. Maka beban limbah budidaya yang masuk ke perairan adalah 5.811,38 $\mathrm{kg} /$ ton udang atau $1.256,38 \mathrm{kgN}, 259,26$ $\mathrm{kgP}$, dan $2.212,91 \mathrm{kgC} /$ ton udang. Alur pemanfaatan N, P dan C pakan dalam budidaya udang karang dalam KJA disajikan dalam Gambar 3.

Beban limbah budidaya dalam KJA untuk menghasilkan 1 ton udang karang adalah 1.256,38 kgN, 259,26 $\mathrm{kgP}$, dan 2.212,91 kgC/ton udang. Dibandingkan dengan penelitian limbah budidaya ikan kerapu dengan pakan ikan rucah, yaitu 174,2 $\mathrm{kgN}(98,3 \%)$; dan $32,4 \mathrm{kgP}(18,1 \%)$ (Noor, 2009), dan budidaya bandeng hanya menghasilkan $42,58 \mathrm{kgN} \quad(55,54 \%) ; \quad 30,87 \quad \mathrm{kgP}$ $(89,79 \%) ; \quad 147,54 \quad \mathrm{~kg} \quad(86,28 \%)$ (Rachmansyah, 2004) (Tabel 3). Walaupun budidaya ikan kerapu dan udang karang menggunakan jenis pakan yang sama yaitu ikan rucah, akan tetapi pada budidaya udang karang nilai RKP lebih yaitu 11,15 dibandingkan ikan kerapu yang hanya 5,9. Selain itu, udang karang bersifat nokturnal dan hanya menunggu makanan, sehingga yang pakan diberikan banyak terbuang ke lingkungan. 


\begin{tabular}{cccccc}
\hline \multicolumn{7}{c}{ (g/ekor) } & $\mathrm{n}=3)$ \\
& \multicolumn{7}{c}{} & & \\
\hline 0 & $15-45$ & $37,00 \pm 2,64$ & $2,42 \pm 0,82$ & $0,25 \pm 0,09$ & $15,46 \pm 3,08$ \\
30 & $31-63$ & $39,67 \pm 5,69$ & $5,13 \pm 1,74$ & $0,92 \pm 0,38$ & $8,24 \pm 3,33$ \\
60 & $46-81$ & $34,33 \pm 14,57$ & $1,51 \pm 0,64$ & $2,19 \pm 1,21$ & $10,94 \pm 3,42$ \\
90 & $61-102$ & $42,00 \pm 6,08$ & $1,95 \pm 1,19$ & $1,37 \pm 0,91$ & $9,15 \pm 0,93$ \\
120 & $75-121$ & $40,33 \pm 4,16$ & $1,79 \pm 0,49$ & $0,96 \pm 0,42$ & $16,30 \pm 3,39$ \\
150 & $90-139$ & $42,00 \pm 6,08$ & $2,38 \pm 0,16$ & $3,95 \pm 0,62$ & $21,39 \pm 1,87$ \\
180 & $106-159$ & $32,00 \pm 6,08$ & $1,77 \pm 0,59$ & $2,69 \pm 0,20$ & $13,54 \pm 0,57$ \\
210 & $121-179$ & $36,33 \pm 8,08$ & $1,38 \pm 0,08$ & $2,96 \pm 0,63$ & $13,73 \pm 1,42$ \\
240 & $136-199$ & $29,67 \pm 6,02$ & $0,87 \pm 0,21$ & $1,45 \pm 0,67$ & $10,50 \pm 1,01$ \\
270 & $151-220$ & $35,00 \pm 10,44$ & $1,43 \pm 0,16$ & $1,77 \pm 0,18$ & $10,68 \pm 1,50$ \\
\hline \multicolumn{7}{c}{36,83} & 2,06 & 1,85 & 12,99 \\
\hline
\end{tabular}

Tingginya beban limbah yang dihasilkan dari budidaya udang karang dalam KJA, perlu mendapat perhatian serius. Walaupun secara ekonomi pakan ikan rucah jauh lebih murah dibandingkan pakan komersial, namun dampak lingkungan akibat penggunaan pakan ikan rucah cukup nyata, dimana ikan rucah memiliki residu limbah lebih tinggi dibanding pakan pellet (Hansen et al., 1990; Chu, 2000), dan sebaran dampak lebih luas (Wu et al., 1994). Beban limbah budidaya yang terbuang ke badan air memberi sumbangan bahan organik yang menyebabkan pengkayaan nutrien (hypernutrifikasi) dan bahan organik hingga mempengaruhi tingkat kesuburan (eutrofikasi) dan kelayakan kualitas air bagi kehidupan ikan budidaya. Beberapa hasil penelitian melaporkan bahwa budidaya intensif dan pengkayaan nutrien berdampak potensial pada perubahan kualitas air (Philips et al. 1993; Boyd, 1999). Oleh karena itu, dalam rangka pengembangan Teluk Ekas sebagai kawasan akuaindustri berbasis budidaya KJA, salah satu aspek yang menjadi perhatian adalah manajemen pakan. Teknik pemberian pakan yang kurang baik, pakan berlebih mengakibatkan lingkungan perairan menjadi kurang baik (Sukadi, 2010). Semakin intensifnya pemberian pakan, residu limbah kegiatan akuakultur akan makin menìngkat. Untuk mengetahui dampak beban limbah budidaya terutama sisa pakan yang terbuat ke badan air, maka dilakukan analisis kualitas perairan Teluk Ekas.

Tabel 2. Nilai parameter penentu beban limbah budidaya udang karang dalam KJA 


\begin{tabular}{ll}
\hline Parameter yang dianalisis & Nilai \\
\hline Rasio konversi pakan (RKP) & 11,15 \\
Kandungan N pakan & $12,80 \%$ \\
Kandungan P pakan & $2,52 \%$ \\
Kandungan C pakan & $29,21 \%$ \\
Bobot awal udang karang & $30 \mathrm{~g} / \mathrm{ekor}$ \\
Bobot akhir udang karang & $182 \mathrm{~g} / \mathrm{ekor}$ \\
Jumlah pakan yang dikonsumsi & $1.1150 \mathrm{~kg}$ \\
Pakan yang terbuang (24\%) & $2.676 \mathrm{~kg}$ \\
Kebutuhan N untuk memproduksi udang karang & $1.427,20 \mathrm{kgN} / \mathrm{ton}$ \\
Kebutuhan P untuk memproduksi udang karang & $278,75 \mathrm{kgP} / \mathrm{ton}$ \\
Kebutuhan C untuk memproduksi udang karang & $3255,80 \mathrm{kgC} / \mathrm{ton}$ \\
Kecernaan bahan kering pakan & $81,77 \%$ \\
Kecernaan N pakan & $85,26 \%$ \\
Kecernaan P pakan & $88,92 \%$ \\
Kecernaan C pakan & $92,67 \%$ \\
Retensi N & $25,12 \%$ \\
Retensi P & $14,64 \%$ \\
Retensi C & $66,93 \%$ \\
\hline
\end{tabular}

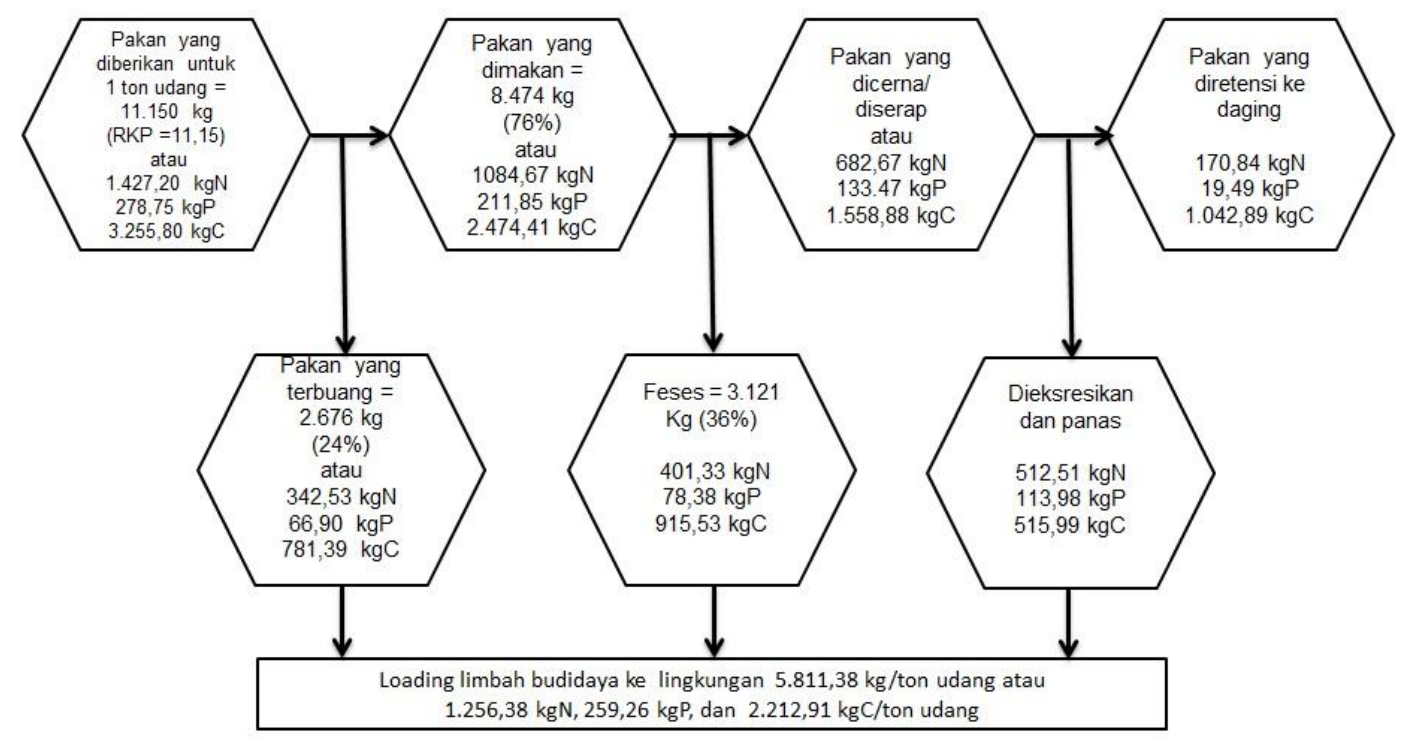

Gambar 3. Alur pemanfaatan N, P dan C pakan untuk memproduksi 1 ton udang karang

Tabel 3. Alur pemanfaatan N, P dan C pakan dalam budidaya berdasarkan beberapa hasil penelitian 


\begin{tabular}{|c|c|c|c|c|c|}
\hline Pakan & Retensi & Feses & $\begin{array}{l}\text { Ekskresi/ter } \\
\text { larut }\end{array}$ & Beban limbah & Pustaka \\
\hline $\begin{array}{l}1427,2 \mathrm{kgN} ; \\
289,98 \mathrm{kgP} ; 3 \\
256,91 \mathrm{kgC} / \mathrm{t} \\
\text { udang }\end{array}$ & $\begin{array}{l}170,84 \mathrm{kgN} ; \\
19,49 \mathrm{kgP} ; \\
1.042,89 \mathrm{kgC} / \mathrm{t} \\
\text { udang }\end{array}$ & $\begin{array}{l}401,33 \\
\text { kgN; } \\
78,38 \mathrm{kgP} ; \\
915,53 \\
\text { kgC/t } \\
\text { udang }\end{array}$ & $\begin{array}{l}512,51 \\
\mathrm{kgN} ; \\
113,98 \\
\mathrm{kgP} ; \\
515,99 \\
\mathrm{kgC/t} \\
\text { udang }\end{array}$ & $\begin{array}{l}1.256,38 \mathrm{kgN} \\
(88,03 \%) ; \\
259,26 \mathrm{kgP} \\
(93,01 \%) ; \\
2.212,91 \mathrm{kgC} / \mathrm{t} \\
\text { udang } \\
(67,97 \%)\end{array}$ & Penelitian ini \\
\hline $\begin{array}{l}177,2 \mathrm{kgN} ; \\
36,5 \mathrm{kgP} / 237,9 \\
\text { kg ikan kerapu }\end{array}$ & $\begin{array}{l}30,7 \mathrm{kgN} ; 4,1 \\
\mathrm{kgP}\end{array}$ & $\begin{array}{l}27,6 \mathrm{kgN} \\
12,7 \mathrm{kgP}\end{array}$ & $\begin{array}{l}114,7 \mathrm{kgN} \\
13,1 \mathrm{kgP}\end{array}$ & $\begin{array}{l}174,2 \mathrm{kgN} \\
(98,3 \%) ; 32,4 \\
\mathrm{kgP}(18,1 \%)\end{array}$ & Noor (2009) \\
\hline $\begin{array}{l}76,66 \mathrm{kgN} ; \\
34,38 \mathrm{kgP} ; \\
170,97 \mathrm{kgC} / \mathrm{t} \\
\text { ikan bandeng }\end{array}$ & $\begin{array}{l}33,77 \mathrm{kgN} ; \\
3,38 \mathrm{kgP} ; \\
22,56 \mathrm{kgC} / \mathrm{t} \\
\text { ikan }\end{array}$ & $\begin{array}{l}4,42 \mathrm{kgN} ; \\
4,42 \mathrm{kgP} \\
6,26 \mathrm{kgC} / \mathrm{t} \\
\text { ikan }\end{array}$ & $\begin{array}{l}38,40 \mathrm{kgN} ; \\
26,24 \mathrm{kgP} \\
140,46 \\
\mathrm{kgC} / \mathrm{t} \text { ikan }\end{array}$ & $\begin{array}{l}42,58 \mathrm{kgN} \\
(55,54 \%) ; 30,87 \\
\mathrm{kgP}(89,79 \%) \\
147,54 \mathrm{kgC/t} \\
\text { ikan }(86,28 \%)\end{array}$ & $\begin{array}{l}\text { Rachmansyah } \\
(2004)\end{array}$ \\
\hline
\end{tabular}

\section{Status Kualitas Perairan Teluk Ekas}

\section{Berdasarkan analisis PCA} menunjukkan bahwa ragam parameter kualitas air pada sumbu utama pertama, kedua, ketiga dan keempat sebesar $83,03 \%$. Hal ini berarti bahwa 83,03\% dari data hasil analisis dapat diterangkan hingga sumbu utama keempat. Namun yang digunakan dalam interpretasi analisis hanya komponen utama pertama (F1) dan kedua (F1). Sumbu pertama memberikan kontribusi terbesar sekitar $29 \%$ dengan penciri utama adalah parameter amonia, DO, suhu dan salinitas (Gambar 4a). Antar parameter penciri utama pada sumbu pertama berkorelasi negatif, dimana peningkatan amonia, DO, suhu dan salinitas mengakibatkan penurunan kadar nitrat, fosfat, $\mathrm{pH}$ dan nitrit perairan Teluk Ekas dengan koefisien korelasi antara 0,090,81 . Sumbu kedua memberikan konstribusi sekitar $27 \%$ dengan penciri utama adalah nitrat, $\mathrm{pH}$, suhu dan salinitas. Antar parameter penciri utama pada sumbu kedua berkorelasi negatif, dimana peningkatan nitrat, fosfat, $\mathrm{pH}$ dan nitrit mengakibatkan penurunan kadar amonia, DO, suhu dan salinitas dengan koefisien korelasi antara 0,14 0,76 .

Berdasarkan sebaran stasiun pengamatan pada sumbu pertama (F1) dan kedua (F2) (Gambar 4b), diperoleh adanya 3 pengelompokan stasiun, hal ini disebabkan perbedaan penciri parameter kualitas air. Stasiun 1, 2, 3, 4, 5, 8 dan 9 dicirikan oleh kadar fosfat dan nitrit, stasiun $12, \quad 13,14$ dan 15 dicirikan oleh suhu dan salinitas, dan stasiun 10 dan 11 dicirikan oleh DO dan amonia. Stasiun yang berdekatan dengan gugusan karang dan mulut teluk dicirikan oleh suhu, fosfat dan DO yang tinggí. Kedalaman yang rendah yang 
diperlukan oleh karang akan memicu peningkatan suhu yang pada gilirannya akan memicu proses fotosintesa yang

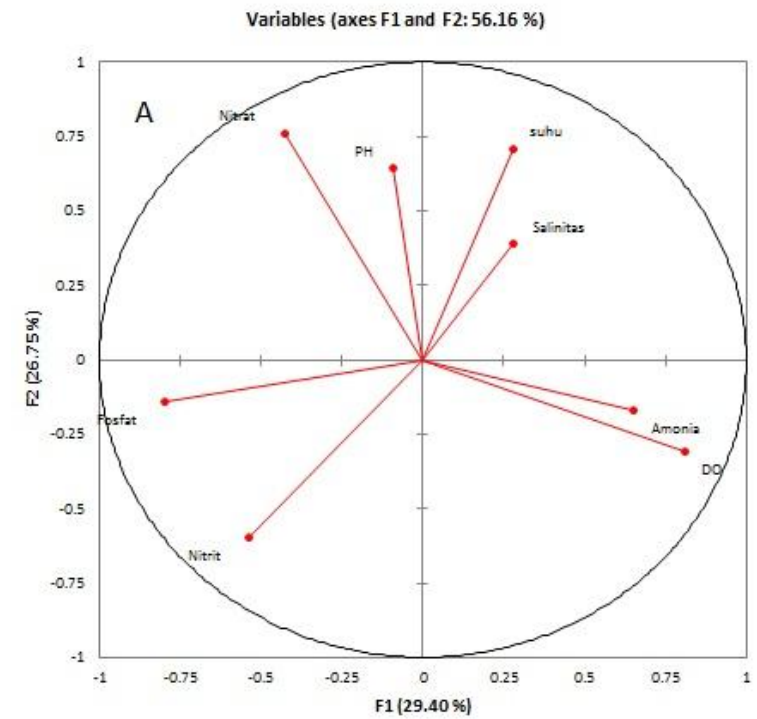

ditopang oleh keberadaan $\mathrm{P}$ sebagai unsur hara sehingga menghasilkan oksigen terlarut.

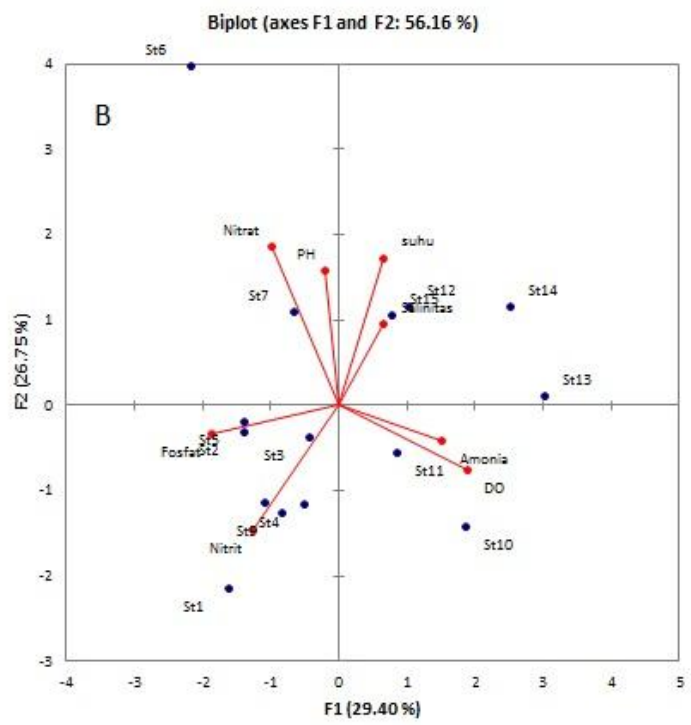

Gambar 4. PCA kualitas air di Teluk Ekas : (a) Ordinasi parameter kualitas air, (b) ordinasi stasiun pengamatan

Penentuan status kualitas perairan

Teluk Ekas berdasarkan Indeks Pencemaran (PI) diperoleh nilai PI berkisar antara $7.01-10.74$ atau termasuk kriteria tercemar sedang sampai tercemar berat, dimana lokasi yang termasuk kriteria tercemar berat hanya pada stasiun 6 (Gambar 5). Parameter kualitas air yang melebihi baku mutu adalah amonia, nitrat dan fosfat, dimana nilai baku mutu untuk amonia $0,3 \mathrm{mg} / \mathrm{l}$, nitrat $0,008 \mathrm{mg} / \mathrm{l}$ dan fosfat $\quad 0,015 \mathrm{mg} / \mathrm{l} \quad(\mathrm{KLH}, \quad 2004)$. Berdasarkan status kualitas perairan tersebut, menunjukkan bahwa limbah budidaya merupakan menyebabkan penurunan kualitas lingkungan perairan, selain pengaruh eksternal (external loading) kegiatan masyarakat di sekitar perairan Teluk Ekas. Penurunan kualitas lingkungan perairan akibat pengaruh limbah budidaya dapat terjadi akibat akumulasi senyawa organik sisa pakan dan faeses di dasar perairan yang bersifat metabolitoksik seperti amonia, nitrat, dan fosfat. Keberadaan phosfat secara berlebihan yang disertai dengan keberadaan nitrogen dapat menstimulir ledakkan pertumbuhan algae di perairan (algae bloom) (Komarawidajaya, 2006). 


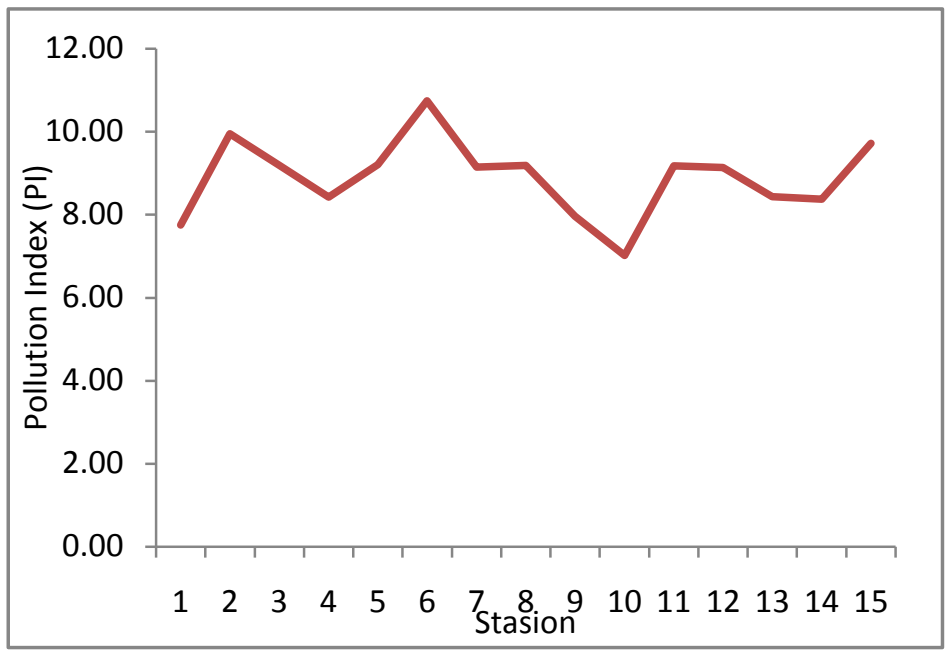

\section{Gambar 5. Nilai PI perairan Teluk Ekas}

Untuk mengantisipasi penurunan kelayakan habitat dan dampaknya terhadap lingkungan perairan budidaya, maka perlu mencari upaya-upaya yang dapat menekan laju buangan limbah tersebut ke dalam lingkungan budidaya, sehingga dapat meminimalkan dampak kegiatan budidaya dalam perairan tersebut. Upaya-upaya yang dapat dilakukan untuk menurunkan beban limbah budidaya ikan di perairan di antaranya adalah (1) pengaturan dengan pembatasan penggunaan pakan ikan rucah, (2) efisiensi pakan melalui teknik pemberian pakan yang baik (frekuensi dan dosis pakan yang tepat) untuk mengurangi sisa pakan yang tidak termakan, (3) penggunaan dan pemilihan bahan baku pakan yang memiliki tingkat kecernaan yang tinggi.

Strategi lain yang perlu diterapkan dalam pengembangan budidaya laut secara berkelanjutan di perairan Teluk Ekas adalah mengembangkan budidaya terpadu (integrated marine farming), dan mengalokasikan sumberdaya budidaya dan akuainput pada lokasi yang dinilai layak dan tidak melebihi daya dukung lingkungan perairan, sehingga diharapkan akan memberikan peluang bagi keberlanjutan usaha budidaya. Karena itu, daya dukung fisik, produksi, sosial dan ekologi harus diperhitungkan dalam mengembangkan akuaindustri berbasis budidaya KJA.

\section{KESIMPULAN DAN SARAN}

Selama pemeliharaan udang karang yang berlangsung 270 hari dengan pemberian pakan ikan rucah, diperoleh laju pertumbuhan harian adalah $0,74 \%$, sintasan $66 \%$ dan dengan rasio konversi pakan 11,15. Beban limbah budidaya udang karang dalam KJA yang terbuang ke lingkungan perairan sebanyak $1.256,38 \mathrm{kgN} ; 259,26$ $\mathrm{kgP}$ dan 2.212,91 kgC/ton produksi udang. Status kualitas perairan Teluk Ekas termasuk kriteria tercemaran sedang sampai tercemar berat, dimana parameter yang melebihi baku mutu adalah amonia $(0,3 \mathrm{mg} / \mathrm{l})$, nitrat $(0,008$ $\mathrm{mg} / \mathrm{l})$, dan fosfat $(0,015 \mathrm{mg} / \mathrm{l})$. Dengan demikian, untuk mengantisipasi penurunan kelayakan habitat dan 
dampaknya terhadap lingkungan perairan budidaya, maka perlu mencari upaya-upaya yang dapat menekan laju buangan limbah tersebut ke dalam lingkungan budidaya, sehingga dapat meminimalkan dampak kegiatan budidaya dalam perairan tersebut.

\section{UCAPAN TERIMA KASIH}

Kami berterima kasih kepada Saudara Darto, S.Pi. dan Andi Mattalata yang membantu dalam pengumpulan data di lapangan, serta pihak Laboratorium Penguji Balai Perikanan Budidaya Laut Lombok atas bantuan dalam analisis kualitas air.

\section{DAFTAR PUSTAKA}

Ackefors, H. and M. Enell. 1990. Discharge of nutriens from Swedish fish farming to adjacent sea areas. Ambio, 19 (11) : 28-35

APHA, 1992. American Public Health Association. Standart Methods for the Examination of Water and Wastewater. American Public Health Association. Washington, DC. 874 p.

Aslianti, T., B. Slamet dan G. S. Prasetya, 2003. Pengembangan budidaya kerapu bebek, Cromileptes altivelis di Teluk Ekas - NTB. Prosiding Seminar Riptek Kelautan Nasional. UPT Baruna Jaya BPPT, Jakarta.

Barg, U.C. 1992. Guidelines for the promotion of environmental management of coastal aquaculture development. FAO Fisheries Technical Paper 328. FAO. Rome. 122 p.

Becira, J.G. and M. Orcajada. 2006. Survivorship and growth performance of red spiny lobster Panulirus longipes longipes reared in floating netcages fed with Sardinella spp at different feeding rates. Science Diliman, 18(1) : 1117.

Becira, J.G. and M. Orcajada. 2006.

Survivorship and growth performance of red spiny lobster Panulirus longipes longipes reared in floating netcages fed with Sardinella spp at different feeding rates. Science Diliman, 18(1) : 1117.

Beveridge, M.C.M. 1987. Cage and pen farming: carrying capacity models and environmental impact. FAO Fish. Tech.Pap.255. FIRI/T255,. Experiment Station, Auburn University, Alabama. 131 p.

Boyd, C.E. 1990. Water Quality in Ponds for Aquaculture. Alabama Agriculture Experimental Station. Auburn University, Auburn

Boyd, C.E., 1999. Management of shrimp ponds to reduce the eutrophication potential of effluents. The Advocate p: 12-13.

Chu, J.C.W. 2000. Enviromental management of marinculture: the effectof feed type on feed waste. RegionalWorkshop on Sustainable Seafarming and Grouper Aquaculture. Collaborative APEC Grouper Research and Development Network (FWG 01/99). Medan 17-20 April 2000.

Gummadi, S., G.S. Latha, G. Vijayajumar, P.B. Rao and V. Venkatarathnamma. 2012. Application of nemwrow's pollution index (NPI) for groundwater quality assessment of bapatla mandal west region, coastal Andhra Pradesh, India. Int. Journal of Applied Sciences and Engineering Research, 4(4) : 500506

Hansen, P.K., Pittman, K. and Ervik, A., 1990. Effects of organic waste 
from marine fish farms on the seabottom beneath the cages. International Council for the Exploration of the Sea. C.M.1990/F:34:9 p.

Islam, M.S. 2005. Nitrogen and phosphorus budget in coastal and marine cage aquaculture and impacts of effluent loading on ecosystem: review and analysis towards model development. Marine Pollution Bulletin 50 (2005) : 48-61

Iwama, G.K. 1991. Interactions between aquaculture and the environment. Crit.Rev.Environ.Control, 21 (2) : 177-216

Jie, C., L. Qing and Q. Hui. 2012. Application of improved Nemerow Index method based on entropy weight for groundwater quality evaluation. International Jurnal Environmental Sciences, 2 (3): 1284 - 1290.

Jones, C.M. 2010. Tropical spiny lobster aquaculture development in Vietnam, Indonesia and Australia. J. Mar. Biol. Ass. India, 52 (2) : 304 - 315, July - December 2010

Jones, C.M., N. V. Long, D. T. Hoc and B. Priyambodo. 2010.

Exploitation of puerulus settlement for the development of tropical spiny lobster aquaculture in the Indo-West Pacific. J. Mar. Biol. Ass. India, 52 (2) : 304 315, July - December 2010

Junaidi, M., S. Andayani, M. Mahmudi dan A. Sartimbul. 2014. Organic matter degradation in Lobster culture system and their effect on waters quality in Ekas Bay, Indonesia. Organic matter degradation in Lobster Culture System and their effect on waters quality in Ekas Bay, Indonesia. Journal of Applied Biotechnology, 2 (1) : 10-23.
KLH (Kementerian Lingkungan Hidup). 2004. Keputusan Menteri Negara Lingkungan Hidup (Kepmen LH) No. 51 tahun 2004 tentang Baku Mutu Air Laut. Menteri Negara Lingkungan Hidup RI. Jakarta

KLH. 2003. Kementerian Lingkungan Hidup. Keputusan Menteri Negara Lingkungan Hidup (Kepmen LH) No. 115 tahun 2003 tentang Pedoman Penentuan Status Mutu Air. Menteri Negara Lingkungan Hidup RI. Jakarta

Krisanti, M. dan Z. Imran. 2006. Daya dukung lingkungan perairan Teluk Ekas untuk pengembangan kegiatan buudidaya ikan kerapu dalam keramba apung. J.Il.Perta.Indon. Vol 11(2): 15-20.

McDonald, M.E., C.A. Tikkanen, R.P. Axler, C.P. Larsen and G. Host. 1996. Fish simulation culture model (FIS-C): a bioenergetics based model for aquacultural wasteload application. Aquacultural Engineering, 15(4):243-259.

Milewski I. 2001. Impacts of salmon aquaculture on the coastal environment: A Review. Proceedings of a Workshop "Marine aquaculture and the environment: a meeting for stakeholders in the Northeast" held January 11 - 13, 2001 at the University of Massachusetts Boston, USA

Noor, A. 2009. Model pengelolaan kualitas lingkungan berbasis daya dukung (Carrying Capacity) perairan teluk bagi pengembangan budidaya keramba jaring apung ikan kerapu (Studi Kasus di Teluk Tamiang, Kabupaten Kotabaru, Propinsi Kalimantan Selatan). Disertasi. Institut Pertanian Bogor. Bogor. 145 hal.

Pearson, T.H. and K.D. Black. 2001. The environmrntal impacts of marine fish cage culture. In K.D. 
Black (ed), Environmental Impact of Aquaculture. CRC Press, Boca Rato, pp 1-31.

Phillips, M.J., R. Clarke and A. Mowat. 1993. Phosphorous leaching from Atlantic Salmon diets.

Aquaculture Engineering, $12: 47$ 54.

Priyambodo, B. and S. Jaya. 2009. Lobster Aquaculture in Eastern Indonesia. Part 1. Methods Evolve for Fledgling Industry. In: Global Aquaculture Advocate, vol. St Louis, Missouri, USA, Global Aquaculture Alliance, p. 36-40.

Priyambodo, B. and Sarifin. 2009. Lobster aquaculture industry in eastern Indonesia: present status and prospects. In: K. C. Williams (Ed.), Proceedings of an International Symposium on Spiny Lobster Aquaculture in the AsiaPacific Region, Australian Centre for International Agricultural Research, Canberra, p. 36-45.

Priyambodo, B. and Sarifin. 2010. Lobster Aquaculture in Eastern Indonesia. Part 2. Ongoing Research Examines Nutritions, Seed Sourcing. In: Global Aquaculture Advocate, vol. St Louis, Missouri, USA, Global Aquaculture Alliance, p. 32-34.

Pusceddu, A., S. Frascahetti, S. Mirto, M. Holmer and R. Danovaro. 2007. Effects of intensive mariculture on sediment biochemistry. Ecological Applications, 17(5) : 1366-1378

Rachmansyah. 2004. Analisis daya dukung lingkungan perairan Teluk Awarange Kabupaten Barru, Sulawesi Selatan bagi pengembangan budidaya bandeng dalam keramba jaring apung. Disertasi. Institut Pertanian Bogor. Bogor. 274 hal.

Setyobudiandi, I., Sulistiono, F. Yulianda, C. Kusmana, S. Hariyadi, A. Damar, A. Sembiringdan Bahtiar. 2009. Sampling dan analisis data perikanan dan kelautan terapan metode pengambilan contoh di wilayah pesisir dan laut. Fakultas Perikanan dan Ilmu Kelautan Institut Pertanian Bogor. Bogor. 312 hal.

Soedibjo, B.S. 2008. Analisis komponen utama dalam kajian ekologi. Oseana Vol. XXXIII (2) :43-53

Sukadi, M.F. 2010. Ketahanan dalam air dan pelepasan nitrogen dan fosfor ke air media dari berbagai pakan ikan air tawar. J. Ris. Akuakultur, 5 (1) : 01-12.

Warren, H. I., 1982. Evaluation of matter discharged from trout farming in Denmark. Report of the EIFAC Workshop on Fish Farm Effluents. FAO/EIFAC Technology P 41:57-63.

Wu, R.S.S., Lam, K.S., MacKey, D.W., Lau, T.C. and Yam, V. 1994. Impact of marine farming on water quality and bottom sediment: A case study in the subtropical environment. Marine Environment Research 38:115145.

Yosmaniar. 2010. Hubungan konversi pakan dengan bebanlimbah hara $\mathrm{N}$ dan P yang terbuang ke air pemeliharaan. Prosiding Forum inovasi Teknologi Akuakultur. 